\title{
Antiepileptic Drug-Induced Apoptosis Was Prevented by L-Type Calcium Channel Activator in Cultured Rat Cortical Cells
}

\author{
Tsuneo Takadera, Masashi Aoki, Naruto Nakanishi \\ Faculty of Pharmaceutical Sciences, Hokuriku University, Kanazawa, Japan \\ Email:t-takadera@hokuriku-u.ac.jp
}

How to cite this paper: Takadera, T., Aoki, M. and Nakanishi, N. (2017) Antiepileptic Drug-Induced Apoptosis Was Prevented by L-Type Calcium Channel Activator in Cultured Rat Cortical Cells. Open Journal of Apoptosis, 6, 17-27. http://dx.doi.org/10.4236/ojapo.2017.62002

Received: January 14, 2017

Accepted: April 4, 2017

Published: April 10, 2017

Copyright (๑) 2017 by authors and Scientific Research Publishing Inc. This work is licensed under the Creative Commons Attribution International License (CC BY 4.0).

http://creativecommons.org/licenses/by/4.0/

\begin{abstract}
Experimental data have shown that antiepileptic drugs cause neurodegeneration in developing rats. Valproate (VPA) is the drug of choice in primary generalized epilepsies, and carbamazepine (CBZ) is one of the most prescribed drugs in partial seizures. These drugs block sodium channels, thereby reducing sustained repetitive neuronal firing. The intracellular mechanisms whereby AEDs induce neuronal cell death are unclear. We examined whether AEDs induce apoptotic cell death in cultured cortical cells and whether calcium ions are involved in the AED-induced cell death. VPA and CBZ increased apoptotic cell death and induced morphological changes that were characterized by cell shrinkage and nuclear condensation or fragmentation. Incubation of cortical cultures with VPA or CBZ decreased phospho-Akt levels. CBZ decreased the intracellular calcium levels. On the other hand, FPL64176, an L-type calcium channel activator, increased the intracellular calcium levels and prevented the AED-induced apoptosis. Glycogen synthase kinase-3 inhibitors, such as alsterpaullone and azakenpaullone, prevented the AED-induced apoptosis. These results suggest that intracellular calcium level changes are associated with AEDs and apoptosis and that the activation of glycogen synthase kinase- 3 is involved in the death of rat cortical neurons.
\end{abstract}

\section{Keywords}

Antiepileptic Drug, Valproate, Carbamazepine, L-Type Calcium Channel, Glycogen Synthase Kinase-3, Apoptosis

\section{Introduction}

Antiepileptic drugs (AEDs) are administered to patients to prevent epileptic seizures. Valproate (VPA) is the drug of choice in primary generalized epilep- 
sies, and carbamazepine (CBZ) is one of the most prescribed drugs in partial seizures. These drugs block sodium channels, thereby reducing sustained repetitive neuronal firing.

AEDs are among the most common teratogens prescribed to women of childbearing potential, and they cause unfavorable effects on cognitive functions when administered to treat seizures in infants and toddlers. For example, fetal valproate exposure causes dose-dependent reduction of cognitive abilities, and these appear to persist at least until the age of 6 [1]. Bittigau et al. [2] reported that exposure to therapeutic levels of AEDs induced neuronal apoptosis in rat brains during the first 2 post-natal weeks. The comparable period in humans begins from the sixth month of pregnancy to several years after birth [3]. Immature human neurons may be vulnerable to neurotoxicity by exposure to AEDs [4]. However, little is known about the intracellular mechanisms whereby AEDs induce neuronal cell death.

Electrical activity plays an important role in neuronal survival. It has been well documented that depolarizing conditions sustain neuronal survival by causing the influx of $\mathrm{Ca}^{2+}$ through L-type $\mathrm{Ca}^{2+}$ channels. When activated by elevated $\mathrm{Ca}^{2+}$, the $\mathrm{Ca}^{2+} /$ calmodulin dependent protein kinase II (CaM-Kinase II) has been reported to mediate the depolarization-dependent survival of neurons [5] [6] [7].

Glycogen synthase kinase-3 (GSK-3) affects many fundamental cellular functions, including the cell cycle, gene transcription, cytoskeletal integrity, and apoptosis [8] [9] [10] [11]. The phosphatidylinositol-3 kinase/Akt (also known as protein kinase B) signaling pathway is one of the signaling systems implicated in the survival of neurons that leads to the inhibition of GSK-3 by increasing serine 9 phosphorylation [8] [12]. Therefore, we examined whether AEDs induce apoptotic cell death in cultured cortical cells and whether calcium ions are involved in the AED-induced cell death. We report here that AEDs induce apoptosis and that an L-type calcium channel activator and GSK-3 inhibitors block apoptosis in cultured rat cortical neurons.

\section{Materials and Methods}

\subsection{Materials}

1-Azakenpaullone was purchased from Merck (Darmstadt, Germany). 2,5-Dimethyl-4-[2-(phenylmethyl)benzoyl]- $1 H$-pyrrole-3-carboxylic acid methyl ester (FPL64176) was purchased from Tocris Bioscience (Bristol, UK). Alsterpaullone and Autocamtide-2-Related Inhibitory Peptide (AIP) were purchased from Sigma Chemical Co. (St. Louis, MO, USA). Rabbit anti-phospho-Akt (Thr308) and anti-Akt antibody were purchased from Cell Signaling Technology, Inc. (Boston, MA, USA). CBZ and other chemicals were purchased from Wako Pure Industries (Osaka, Japan).

\subsection{Cell Culture}

Cerebral cortical cells were obtained and cultured, as described by Dichter [13] and Choi et al. [14], from fetal rats (Wistar) after 18 - 19 days of gestation. The 
dissociated cortical cells were cultured on poly-D-lysine-coated $35 \mathrm{~mm}$ dishes (Falcon 3001) $\left(2 \times 10^{6}\right.$ cells/dish $)$ in Dulbecco's modified Eagle's medium (DMEM) containing $10 \%$ fetal calf serum. Ten $\mu \mathrm{M}$ cytosine- $\beta$-D arabinofuranoside was added to the culture medium on day 3 after plating. The cells were cultured for 9 - 10 days prior to use in experiments. The proportion of neurons to glia cells was approximately $95 \%$.

\subsection{Cell Treatment and Cell Viability}

The cells were washed twice with Tris-buffered salt solution containing (in $\mathrm{mM}$ ) $\mathrm{NaCl} 120, \mathrm{KCl} 5.4, \mathrm{CaCl}_{2} 1.8, \mathrm{MgCl}_{2}$ 0.8, Tris- $\mathrm{HCl} 25$, and glucose 15 at $\mathrm{pH} 6.5$, and then replaced with $2 \mathrm{ml}$ of DMEM. Washing buffer at $\mathrm{pH} 6.5$ was used to block glutamate neurotoxicity during treatment. Reagents, such as carbamazepine, were subsequently added to the cells. This treatment was carried out for 1 2 days at $37^{\circ} \mathrm{C}$. Morphological changes in the cells were assessed by phase-contrast microscopy. Apoptotic cell death was determined by staining the cells with Hoechst dye H33258. Cells were fixed with a $10 \%$ formalin neutral phosphate buffer solution ( $\mathrm{pH}$ 7.4) for $5 \mathrm{~min}$ at room temperature. After washing the cells with distilled water, they were stained with $8 \mu \mathrm{g} / \mathrm{ml}$ of $\mathrm{H} 33258$ for $5 \mathrm{~min}$. Nuclear morphology was observed under a fluorescent microscope (Olympus IX70 model). Apoptosis was quantified by scoring the percentage of cells with the apoptotic nuclear morphology at the single cell level. Condensed or fragmented nuclei were scored as apoptotic. A total of 5 - 7 randomly selected fields were captured using WRAYCAM software (Wraymer, Osaka). At least 200 cells were counted per condition, and each experiment was repeated in at least 3 different cultures [15].

\subsection{Western Blotting}

Primary cultured cells were scraped off the dish and collected by centrifugation $(400 \times \mathrm{g}$ for $5 \mathrm{~min})$, followed by homogenization in ice-cold buffer $(50 \mathrm{mM}$ Tris- $\mathrm{HCl}$ buffer containing $50 \mathrm{mM} \mathrm{NaCl}, 10 \mathrm{mM}$ EGTA, $5 \mathrm{mM}$ EDTA, $2 \mathrm{mM}$ sodium pyrophosphate, $1 \mathrm{mM}$ sodium orthovanadate, $1 \mathrm{mM}$ benzamide, and $10 \%$ protease inhibitor cocktail, $\mathrm{pH}$ 7.4). The cell suspension was placed on ice for $30 \mathrm{~min}$ and centrifuged at $18,000 \times g$ for $30 \mathrm{~min}$. The supernatant was diluted with an equal volume of sample buffer containing $62.5 \mathrm{mM}$ Tris- $\mathrm{HCl}(\mathrm{pH}$ 6.8 ), $2 \%$ sodium dodecyl sulfate (SDS), $10 \%$ glycerol, $50 \mathrm{mM}$ dithiothreitol, and $0.1 \%$ bromophenol blue, heated at $95^{\circ} \mathrm{C}$ for $5 \mathrm{~min}$ and stored at $-20^{\circ} \mathrm{C}$. Protein concentration was determined by the bicinchoninic acid assay. Each sample (20 $\mu \mathrm{g} / \mathrm{lane})$ was loaded and separated using 7.5\% SDS-polyacrylamide gel electrophoresis. Proteins were transferred on a PVDF membrane and incubated with a blocking buffer for $1 \mathrm{~h}$ at room temperature, then incubated with an anti-phospho-Akt (Thr308) antibody and an anti-Akt polyclonal antibody in Trisbuffered saline overnight at $4^{\circ} \mathrm{C}$. After washing for $5 \mathrm{~min}$ with three changes of Tris-buffered saline, the membrane was incubated with a phosphatase-conjugated goat anti-rabbit antibody for $1 \mathrm{~h}$ at room temperature in Tris-buffered sa- 
line. After washing for 5 min with three changes of Tris-buffered saline, immunoreactive bands were visualized with a Western blot detection kit BCIP/NBT system.

\subsection{Measurement of Intracellular Calcium Levels}

Changes in the intracellular calcium levels in cortical cells were monitored by $\mathrm{Ca}^{2+}$ sensitive fluorescent dye fluo-4. Cells cultured on the cover glass mounted on the bottom of the dish were incubated with DMEM containing $5 \mu \mathrm{M}$ Fluo- 4 acetoxymethyl ester and $0.04 \%$ Pluronic $\mathrm{F} 127$ for $60 \mathrm{~min}$ at $37^{\circ} \mathrm{C}$, and then the

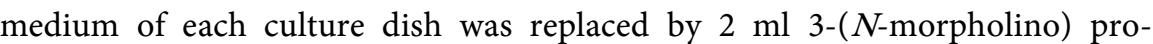
pane-sulfonic acid (MOPS) buffer (in mM: MOPS 10, $\mathrm{NaCl} 145, \mathrm{KCl} 5, \mathrm{MgCl}_{2} 1$, $\mathrm{Na}_{2} \mathrm{HPO}_{4} 1, \mathrm{CaCl}_{2}$ 1.8, glucose 15; pH 7.4). An LSM 510 scanning system (Zeiss $\mathrm{GmbH}$, Jena, Germany) was used for confocal imaging of $\mathrm{Ca}^{2+}$ fluorescence. The fluorescence intensity values obtained from cells in a fixed area of each dish were taken at intervals of $0.5 \mathrm{~min}$ at room temperature.

\subsection{Statistical Analysis}

Statistical significance was assessed by one-way ANOVA and post hoc Scheffe's comparisons.

\section{Results}

\subsection{VPA and CBZ Induced Apoptotic Cell Death in Cultured Cortical Neurons}

We examined the effect of AEDs (VPA and CBZ) on cultured rat cortical cells. After the cortical neurons were treated with $100 \mu \mathrm{M}$ VPA or CBZ for $48 \mathrm{~h}$, the cells showed apoptotic morphology, which included shrunken cell bodies, fragmented processes, and condensed or fragmented nuclei (Figure 1). Up to 35\% $40 \%$ of neurons showed apoptotic cell death after treatment with $50-200 \mu \mathrm{M}$ VPA or CBZ for $48 \mathrm{~h}$ in a dose-dependent manner (Figure 2).

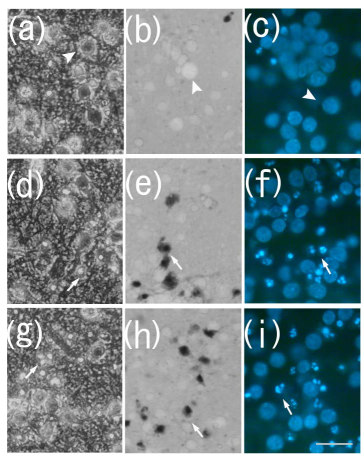

Figure 1. AED-induced apoptosis. Phase-contrast ((a), (d), (g)), trypan blue staining ((b), (e), (h)), and H33258 fluorescence ((c), (f), (i)) microscopy images of cortical cells after exposure to AEDs. Cells were incubated in the absence (a)-(c) or presence of $100 \mu \mathrm{M}$ VPA (d)-(f) or $100 \mu \mathrm{M} \mathrm{CBZ} \mathrm{(g)-(i)} \mathrm{for} 48 \mathrm{~h}$ at $37^{\circ} \mathrm{C}$ as described in the materials and methods section. Scale bars $=50 \mu \mathrm{m}$. Arrowheads indicate healthy neurons. Arrows indicate neurons with apoptotic morphology. 
Protein synthesis is required for the apoptosis of many cell types. The apoptotic cell death induced by VPA or CBZ was attenuated by the presence of 0.1 $\mu \mathrm{g} / \mathrm{mL}$ cycloheximide, a protein synthesis inhibitor, which indicated that the synthesis of new proteins was required for AED-induced apoptosis (Figure 3).

\subsection{AED Decreased Akt Phosphorylation Levels}

Akt is phosphorylated at two sites that are associated with activation of enzyme activity; Thr308 in the catalytic domain, and Ser473 in the cytoplasmic domain. Akt phosphorylation at Thr308 was determined by immunoblot analysis utilizing a phospho-Akt-(Thr308)-specific antibody. Incubation of cortical cultures with $100 \mu \mathrm{M}$ VPA or CBZ for $24 \mathrm{~h}$ decreased phospho-Akt levels (Figure 4). The inhibition caused by VPA or CBZ was $33 \%$ or $43 \%$, respectively.

\subsection{AED Decreased Intracellular Calcium Levels, and L-Type Calcium Channel Agonist Inhibited the Decrease in Calcium Levels}

We examined the alterations in $\left[\mathrm{Ca}^{2+}\right]_{\mathrm{i}}$ induced by CBZ. The addition of $100 \mu \mathrm{M}$ $\mathrm{CBZ}$ decreased the calcium levels (Figure 5). The decrease in the $\left[\mathrm{Ca}^{2+}\right]_{\mathrm{i}}$ due to
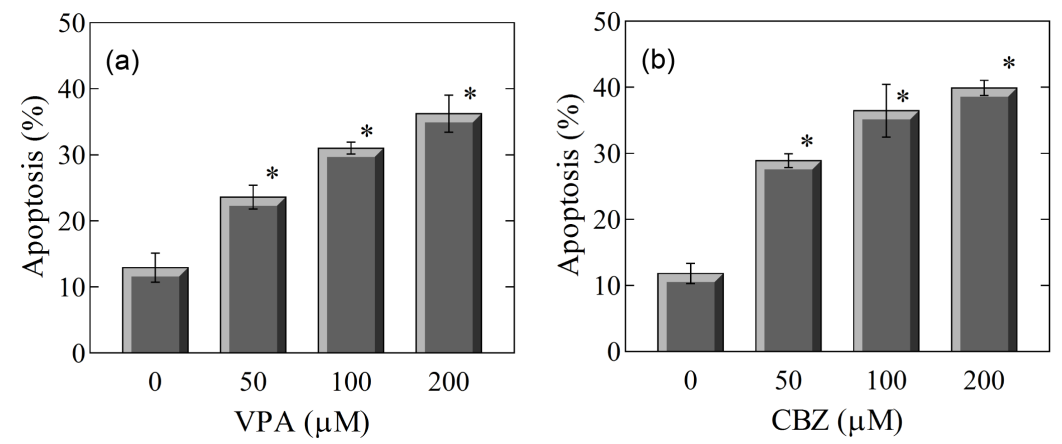

Figure 2. Dose dependency of AED-induced apoptosis. (a) The cells were incubated with or without VPA $(50 \mu \mathrm{M}$ to $200 \mu \mathrm{M})$ for $48 \mathrm{~h}$ at $37^{\circ} \mathrm{C}$. Data are shown as the mean \pm S.E.M. $\mathrm{n}=3$ per group. ${ }^{\star} \mathrm{P}<0.05$ (vs. control cells). (b) The cells were incubated with or without CBZ $(50 \mu \mathrm{M}$ to $200 \mu \mathrm{M})$ for $48 \mathrm{~h}$ at $37^{\circ} \mathrm{C}$. Data are shown as the mean \pm S.E.M. $\mathrm{n}=3$ per group. ${ }^{\star} \mathrm{P}<0.05$ (vs. control cells).

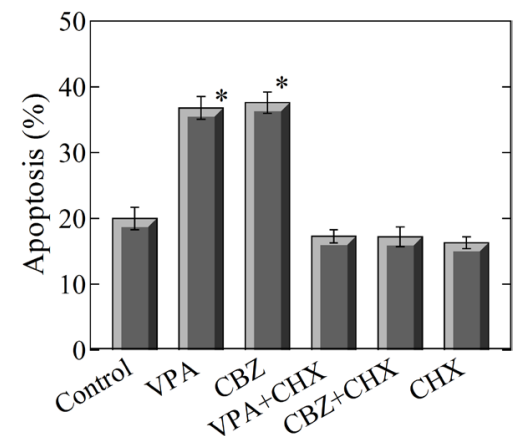

Figure 3. Effect of cycloheximide on AED-induced apoptosis. The cells were incubated with VPA $(100 \mu \mathrm{M})$ or CBZ $(100 \mu \mathrm{M})$ in the presence or absence of $0.1 \mu \mathrm{g} / \mathrm{ml}$ cycloheximide for $48 \mathrm{~h}$ at $37^{\circ} \mathrm{C}$. Each value represents the mean \pm S.E.M. $\mathrm{n}=3$ per group. ${ }^{\star} \mathrm{P}<$ 0.05 (vs. control cells). 


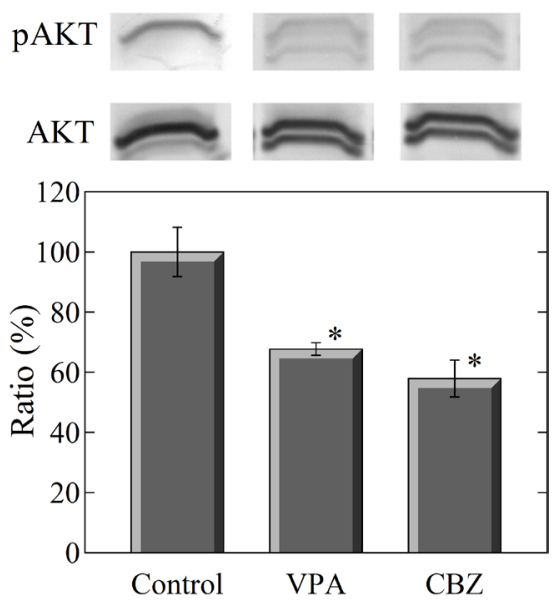

Figure 4. AED decreased Akt phosphorylation levels. The cells were treated with or without VPA $(100 \mu \mathrm{M})$ or CBZ $(100 \mu \mathrm{M})$ for $24 \mathrm{~h}$ at $37^{\circ} \mathrm{C}$. Equal amounts of protein extracts were analyzed by western blot analysis with anti-phosphor-Akt (Thr308) or anti-Akt antibody. Data are expressed as a percentage of the optical density value for control. Data are shown as the mean \pm S.E.M. $\mathrm{n}=3$ per group. ${ }^{\star} \mathrm{P}<0.05$ (vs. control cells).

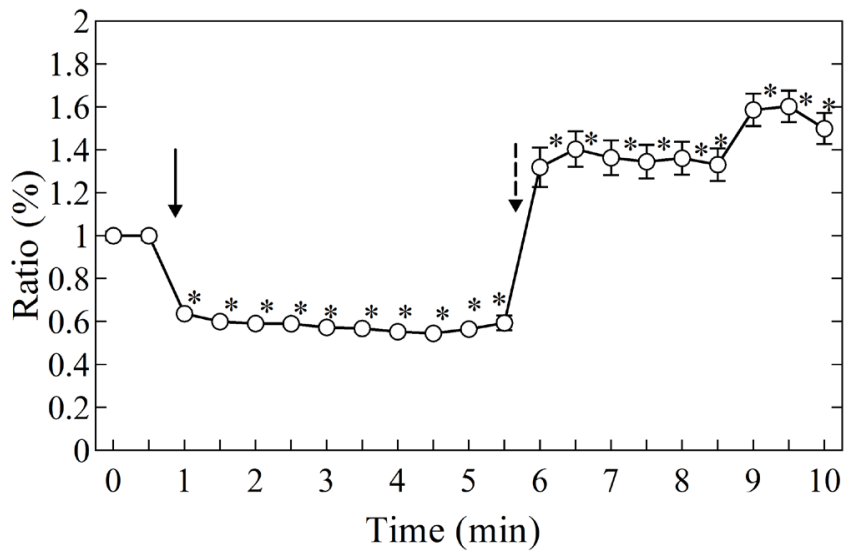

Figure 5. AED decreased and L-type calcium channel activator increased intracellular calcium levels. The fluorescence intensity values obtained from 100 cells in a fixed area of each dish were taken at intervals of $0.5 \mathrm{~min}$ using the fluorescent indicator fluo- 4 and laser scanning confocal microscopy as described in Materials and Methods. CBZ (100 $\mu \mathrm{M})$ and FPL64176 $(20 \mu \mathrm{M})$ were added to the cells at the time indicated by the solid line arrow and the dotted line arrow, respectively. Data are shown as the mean \pm S.E.M. ${ }^{\star} \mathrm{P}<$ 0.05 (vs. time zero).

CBZ was inhibited by the addition of FPL64176, an L-type calcium channel agonist, to the CBZ-treated cells. Moreover, FPL64176 increased the basal calcium levels.

\subsection{L-Type Calcium Channel Agonist Prevented Apoptosis Induced by AEDs}

We next examined whether the activation of $\mathrm{Ca}^{2+}$ influx by voltage-dependent calcium channels prevented the AED-induced apoptosis. We assayed the effects of FPL64176 on the apoptosis induced by VPA or CBZ. As shown in Figure 6, FPL64176 prevented the apoptosis induced by the AEDs. 


\subsection{CaM-Kinase II Inhibitors Attenuated L-Type Calcium Channel Agonist-Induced Protection of Cells from AED-Induced Apoptosis}

To elucidate the downstream signaling pathway through which the FPL64176induced $\left[\mathrm{Ca}^{2+}\right]_{\mathrm{i}}$ signal mediated its protective effect on AED-induced apoptosis, we investigated the effects of the CaM-kinase II inhibitor, KN93, and its inactive analog, KN92, on the FPL64176-induced protective effect on CBZ-induced apoptosis. The protective effect of FPL64176 on CBZ-induced apoptosis was reduced after treatment with KN93, but not KN92 (Figure 7(a)). In addition, autocamtide-2-related inhibitory peptide (AIP), another CaM-kinase II inhibitor, also reduced the protective effect of FPL64176 on CBZ-induced apoptosis (Figure 7(b)).

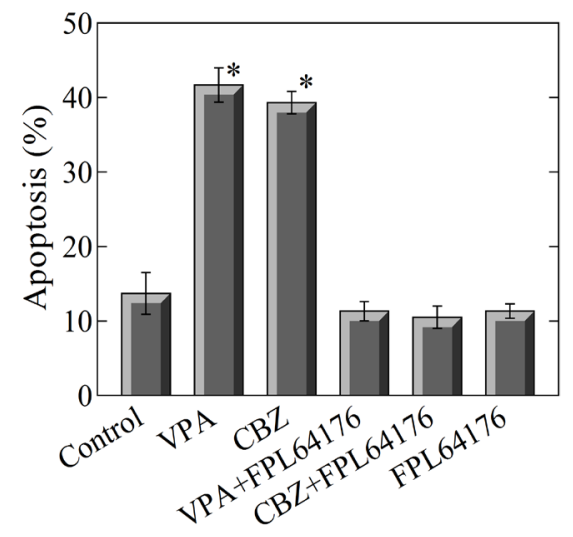

Figure 6. Protective effect of L-type calcium channel activator on AED-induced apoptosis. The cells were incubated with $100 \mu \mathrm{M}$ VPA or CBZ for $48 \mathrm{~h}$ at $37^{\circ} \mathrm{C}$ in the presence or absence of $20 \mu \mathrm{M}$ FPL64176, an L-type calcium channel activator. Data are shown as the mean \pm S.E.M. $n=3$ per group. ${ }^{\star} \mathrm{P}<0.05$ (vs. control cells).
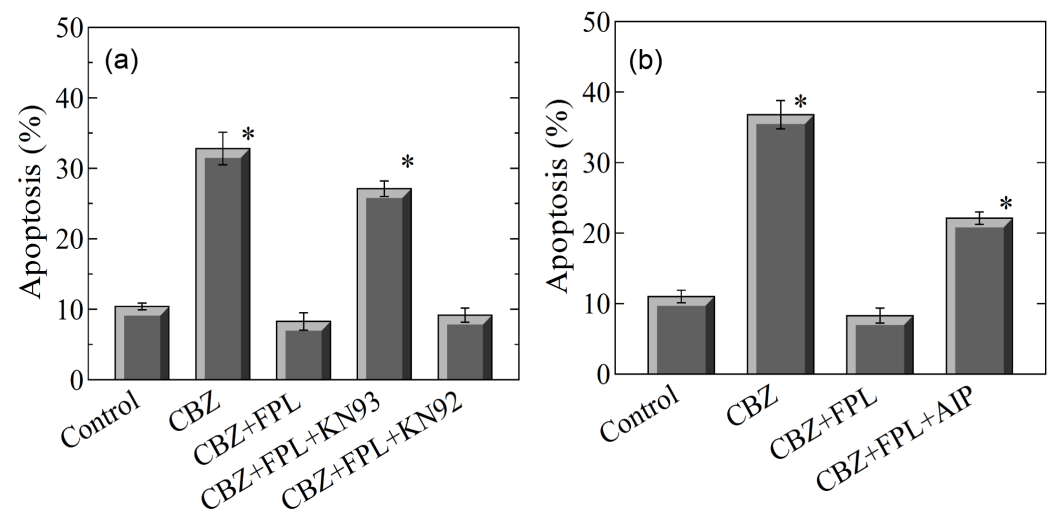

Figure 7. Effect of CaM-Kinase II inhibitors on L-type calcium channel activator-induced protection. (a) The cells were incubated with or without CBZ $(100 \mu \mathrm{M})$ or CBZ $(100 \mu \mathrm{M})+$ FPL64176 $(20 \mu \mathrm{M})$ in the presence or absence of CaM-Kinase II inhibitor, KN93, $(5 \mu \mathrm{M})$ and its inactive analog, $\mathrm{KN} 92,(5 \mu \mathrm{M})$ for $48 \mathrm{~h}$ at $37^{\circ} \mathrm{C}$. Each value represents the mean \pm S.E.M. $\mathrm{n}=3$ per group. ${ }^{\star} \mathrm{P}<0.05$ (vs. control cells). (b) The cells were incubated with or without CBZ $(100 \mu \mathrm{M})$ or CBZ $(100 \mu \mathrm{M})+$ FPL64176 $(20 \mu \mathrm{M})$ in the presence or absence of CaM-Kinase II inhibitor, AIP, $(40 \mu \mathrm{M})$ for $48 \mathrm{~h}$ at $37^{\circ} \mathrm{C}$. Each value represents the mean \pm S.E.M. $n=3$ per group. ${ }^{\star} \mathrm{P}<0.05$ (vs. control cells). 


\subsection{Inhibitors of GSK-3 Prevented Apoptosis Induced by AEDs}

The principal physiological substrate of Akt is GSK-3, and its activity is inhibited by Akt-mediated phosphorylation in response to trophic stimulation. To investigate the role of endogenous GSK-3 activity in inducing cell death in response to AED treatment, we assayed the effects of selective inhibitors, alsterpaullone and azakenpaullone, on VPA- or CBZ-induced apoptosis. The GSK-3 inhibitors showed a protective effect against VPA- or CBZ-induced apoptosis (Figure 8).

\section{Discussion}

AEDs are thought to act on voltage-dependent sodium channels, inhibitory neurotransmitters, or glutamatergic excitatory neurotransmitters. The effect of AEDs is commonly ascribed to a voltage-dependent inhibitory effect on voltage-gated sodium channels [16] [17] [18].

We showed that VPA and CBZ induced apoptosis and an L-type calcium channel activator prevented the VPA- and CBZ-induced apoptosis, suggesting that $\mathrm{Ca}^{2+}$ is a component for survival signaling, possibly through CaM-Kinase II in cortical neurons. It is possible that the AED-induced apoptosis is due to the decrease in intracellular $\mathrm{Ca}^{2+}$ levels maintained by L-type $\mathrm{Ca}^{2+}$ channels under depolarizing conditions. It has been well documented that depolarizing conditions (such as elevated $[\mathrm{KCl}]_{\mathrm{o}}$ ) sustain neuronal survival by causing the influx of $\mathrm{Ca}^{2+}$ through L-type $\mathrm{Ca}^{2+}$ channels in cerebellar granule neurons [5] [19] [20]. However, we cannot exclude the possibility that AEDs, such as CBZ, interfere with the sodium channel-mediated release of glutamate in nerve endings [21] and then inhibit the calcium influx through NMDA receptors (a subtype of ionotropic glutamate receptors) [22].

Akt is activated by $\mathrm{Ca}^{2+}$ influx through L-type $\mathrm{Ca}^{2+}$ channels and NMDA receptors [6] [23] [24] [25]. When activated by elevated $\mathrm{Ca}^{2+}$, the $\mathrm{Ca}^{2+} /$ calmodulin dependent protein kinase II (CaM-Kinase II) has been reported to mediate the depolarization-dependent survival of neurons [5] [6] [7].

We showed that the GSK-3 inhibitors protected cortical neurons from the apoptosis induced by VPA and CBZ, suggesting that GSK-3 activity is critical for
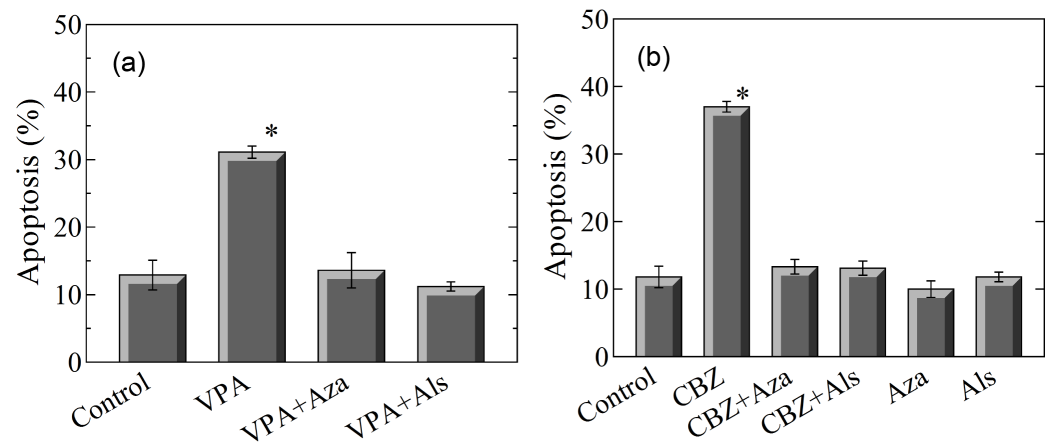

Figure 8. Protective effect of GSK-3 inhibitors on AED-induced apoptosis. The cells were incubated with $100 \mu \mathrm{M}$ VPA or CBZ for $48 \mathrm{~h}$ at $37^{\circ} \mathrm{C}$ in the presence or absence of $2 \mu \mathrm{M}$ azakenpaullone or $1 \mu \mathrm{M}$ alsterpaullone. Each value represents the mean \pm S.E.M. $\mathrm{n}=3$ per group. ${ }^{\star} \mathrm{P}<0.05$ (vs. control cells). Aza, azakenpaullone; Als, alsterpaullone. 
neuronal cell death. GSK-3 activity is suppressed when it becomes phosphorylated on serine 9 by the activation of Akt [7] [8] [12]. However, the activities of the downstream substrates of GSK-3 that ultimately induce neuronal death are not clear. Linseman et al. [26] have reported that GSK-3 phosphorylates Bax, a pro-apoptotic Bcl-2 family member that stimulates the intrinsic (mitochondrial) death pathway by eliciting cytochrome $c$ release from mitochondria, and promotes its mitochondrial localization.

We showed that AEDs induced apoptosis and that an L-type calcium channel activator and GSK-3 inhibitors blocked the apoptosis in cultured rat cortical neurons, suggesting that the L-type calcium channel and GSK-3 are involved in cell death.

\section{Acknowledgements}

This study was supported by The Specific Research Fund of Hokuriku University.

\section{References}

[1] Velez-Ruiz, N.J. and Meador, K.J. (2015) Neurodevelopmental Effects of Fetal Antiepileptic Drug Exposure. Drug Safety, 38, 271-278.

https://doi.org/10.1007/s40264-015-0269-9

[2] Bittigau, P., Sifringer, M., Genz, K., Reith, E., Pospischil, D., Govindarajalu, S., Dzietko, M., Pesditschek, S., Mai, I., Dikranian, K., Olney, J.W. and Ikonomidou, C. (2002) Antiepileptic Drugs and Apoptotic Neurodegeneration in the Developing Brain. Proceedings of the National Academy of Sciences of the United States of America, 99, 15089-15094. https://doi.org/10.1073/pnas.222550499

[3] Dobbing, J. and Sands, J. (1979) Comparative Aspects of the Brain Growth Spurt. Early Human Development, 3, 79-83. https://doi.org/10.1016/0378-3782(79)90022-7

[4] Turski, C.A. and Ikonomidou, C. (2012) Neuropathological Sequelae of Developmental Exposure to Antiepileptic and Anesthetic Drugs. Frontiers in Neurology, 3, 120. https://doi.org/10.3389/fneur.2012.00120

[5] Ghosh, A. and Greenberg, M.E. (1995) Calcium Signaling in Neurons: Molecular Mechanisms and Cellular Consequences. Science, 268, 239-247.

https://doi.org/10.1126/science.7716515

[6] Borodinsky, L.N., Coso, O.A. and Fiszman, M.L. (2002) Contribution of $\mathrm{Ca}^{2+} \mathrm{Cal}-$ modulin-Dependent Protein Kinase II and Mitogen-Activated Protein Kinase Kinase to Neural Activity-Induced Neurite Outgrowth and Survival of Cerebellar Granule Cells. Journal of Neurochemistry, 80, 1062-1070.

https://doi.org/10.1046/j.1471-4159.2002.00795.x

[7] Vaillant, A.R., Mazzoni, I., Tudan, C., Boudreau, M., Kaplan, D.R. and Miller, F.D. (1999) Depolarization and Neurotrophins Converge on the Phosphatidylinositol 3-Kinase-Akt Pathway to Synergistically Regulate Neuronal Survival. The Journal of Cell Biology, 146, 955-966. https://doi.org/10.1083/jcb.146.5.955

[8] Cross, D.A., Alessi, D.R., Cohen, P., Andjelkovich, M. and Hemmings, B.A. (1995) Inhibition of Glycogen Synthase Kinase- 3 by Insulin Mediated by Protein Kinase B. Nature, 378, 785-789. https://doi.org/10.1038/378785a0

[9] Grimes, C.A. and Jope, R.S. (2001) The Multifaceted Roles of Glycogen Synthase Kinase 3Beta in Cellular Signaling. Progress in Neurobiology, 65, 391-426. 
[10] Hetman, M., Cavanaugh, J.E., Kimelman, D. and Xia, Z. (2000) Role of Glycogen Synthase Kinase-3Beta in Neuronal Apoptosis Induced by Trophic Withdrawal. The Journal of Neuroscience, 20, 2567-2574.

[11] Takadera, T., Sakamoto, Y. and Ohyashiki, T. (2004) NMDA Receptor 2B-Selective Antagonist Ifenprodil-Induced Apoptosis Was Prevented by Glycogen Synthase Kinase-3 Inhibitors in Cultured Rat Cortical Neurons. Brain Research, 1020, 196203.

[12] Pap, M. and Coope,G.M. (1998) Role of Glycogen Synthase Kinase-3 in the Phosphatidylinositol 3-Kinase/Akt Cell Survival Pathway. The Journal of Biological Chemistry, 273, 19929-19932.

[13] Dichter, M.A. (1978) Rat Cortical Neurons in Cell Culture: Culture Methods, Cell Morphology, Electrophysiology, and Synapse Formation. Brain Research, 149, 279293.

[14] Choi, D.W., Koh, J.Y. and Peters, S. (1988) Pharmacology of Glutamate Neurotoxicity in Cortical Cell Culture: Attenuation by NMDA Antagonists. The Journal of Neuroscience, 8, 185-196.

[15] Takadera, T., Matsud, I. and Ohyashiki, T. (1999) Apoptotic Cell Death and Caspase-3 Activation Induced by N-Methyl-D-Aspartate Receptor Antagonists and Their Prevention by Insulin-Like Growth Factor I. Journal of Neurochemistry, 73, 548-556. https://doi.org/10.1046/j.1471-4159.1999.0730548.x

[16] Kapetanovic, I.M., Yonekawa, W.D. and Kupferberg, H.J. (1995) The Effects of Anticonvulsant Compounds on 4-Aminopyridine-Induced de Novo Synthesis of Neurotransmitter Amino Acids in Rat Hippocampus in Vitro. Epilepsy Research, 20, 113-120. https://doi.org/10.1016/0920-1211(94)00071-4

[17] Kuo, C.C., Chen, R.S., Lu, L. and Chen, R.C. (1997) Carbamazepine Inhibition of Neuronal $\mathrm{Na}^{+}$Currents: Quantitative Distinction from Phenytoin and Possible Therapeutic Implications. Molecular Pharmacology, 51, 1077-1083.

[18] Rush, A.M. and Elliott, J.R. (1997) Phenytoin and Carbamazepine: Differential Inhibition of Sodium Currents in Small Cells from Adult Rat Dorsal Root Ganglia. Neuroscience Letters, 226, 95-98.

[19] Song, B., Lai, B., Zheng, Z., Zhang, Y., Luo, J., Wang, C., Chen, Y., Woodgett, J.R. and Li, M. (2010) Inhibitory Phosphorylation of GSK-3 by CaMKII Couples Depolarization to Neuronal Survival. The Journal of Biological Chemistry, 285, 4112241134. https://doi.org/10.1074/jbc.M110.130351

[20] Gallo, V., Kingsbury, A., Balázs, R. and Jørgensen, O.S. (1987) The Role of Depolarization in the Survival and Differentiation of Cerebellar Granule Cells in Culture. The Journal of Neuroscience, 7, 2203-2213.

[21] Sitges, M., Chiu, L.M., Guarneros, A. and Nekrassov, V. (2007) Effects of Carbamazepine, Phenytoin, Lamotrigine, Oxcarbazepine, Topiramate and Vinpocetine on $\mathrm{Na}^{+}$Channel-Mediated Release of $\left[{ }^{3} \mathrm{H}\right]$ Glutamate in Hippocampal Nerve Endings. Neuropharmacology, 52, 598-605.

[22] Gao, X.M., Margolis, R.L., Leeds, P., Hough, C., Post, R.M. and Chuang, D.M. (1995) Carbamazepine Induction of Apoptosis in Cultured Cerebellar Neurons: Effects of $\mathrm{N}$-Methyl-D-Aspartate, Aurintricarboxylic Acid and Cycloheximide. Brain Research, 703, 63-71.

[23] Takadera, T., Ishida, A. and Ohyashiki, T. (2006) Ketamine-Induced Apoptosis in Cultured Rat Cortical Neurons. Toxicology and Applied Pharmacology, 210, 100107.

[24] Sutton, G. and Chandler, L.J. (2002) Activity-Dependent NMDA Receptor-Mediated Activation of Protein Kinase B/Akt in Cortical Neuronal Cultures. Journal of 
Neurochemistry, 82, 1097-1105. https://doi.org/10.1046/j.1471-4159.2002.01031.x

[25] Okuno, S., Kitani, T., Matsuzaki, H., Konishi, H., Kikkawa, U. and Fujisawa, H. (2000) Studies on the Phosphorylation of Protein Kinase B by $\mathrm{Ca}^{2+} /$ CalmodulinDependent Protein Kinases. Journal of Biochemistry, 127, 965-970.

https://doi.org/10.1093/oxfordjournals.jbchem.a022712

[26] Linseman, D.A., Butts, B.D., Precht, T.A., Phelps, R.A., Le, S.S., Laessig, T.A., Bouchard, R.J., Florez-McClure, M.L. and Heidenreich, K.A. (2004) Glycogen Synthase Kinase- $3 \beta$ Phosphorylates Bax and Promotes Its Mitochondrial Localization during Neuronal Apoptosis. The Journal of Neuroscience, 24, 9993-10002.

https://doi.org/10.1523/JNEUROSCI.2057-04.2004

Submit or recommend next manuscript to SCIRP and we will provide best service for you:

Accepting pre-submission inquiries through Email, Facebook, LinkedIn, Twitter, etc. A wide selection of journals (inclusive of 9 subjects, more than 200 journals)

Providing 24-hour high-quality service

User-friendly online submission system

Fair and swift peer-review system

Efficient typesetting and proofreading procedure

Display of the result of downloads and visits, as well as the number of cited articles Maximum dissemination of your research work

Submit your manuscript at: http://papersubmission.scirp.org/

Or contact ojapo@scirp.org 